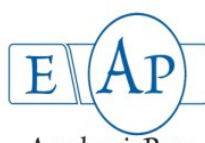

AcademicPres

\title{
Population Structure and Some Growth Properties of Gibel Carp (Carassius gibelio) in a Mesotrophic Lake
}

\author{
Hakki DERELİ', Ezgi DİNÇTÜRK
}

'Izmir Katip Celebi University, Faculty of Fisheries, 35620, Cigli, Izmir,Turkey; hakki.dereli@ikc.edu.tr ("correspondingauthor); ezgi.dincturk@ikc.edu.tr

\begin{abstract}
The hereby study investigated gibel carp (Carassius gibelio) in a mesotrophic lake (Lake Beyşehir, Turkey) from April 2013 to March 2014, in order to outline population structure and some growth properties of the species. Two water quality variables (Chlorophyll-a, Trophic State Index (TSI)) were detected seasonally to define trophic status of the lake. Length and weight distributions, length - weight relationship, sex ratio, gonadosomatic index (GSI), condition factor (CF) and von Bertalanffy equation were calculated for $C$. gibelio sampled monthly. Trophic status of the lake was defined as mesotrophic. Total length and weight of $C$. gibelio samples was determined in the range of 8.5 and $28.4 \mathrm{~cm}$ and 15 and $408 \mathrm{~g}$, respectively. Mean total length and weight of individuals were calculated as $17.5 \pm 2.37 \mathrm{~cm}$ and $88.6 \pm 39.02 \mathrm{~g}$, respectively. There was a negative allometry between length and weight for $C$. gibelio. The fish samples were composed of $52 \%$ females and 48\% males, between II and VII years old. Spawning period of the species occurred between April and June after GSI values reached their maximum in March. The CF values were validated between 1.5-1.7 besides the mean rate of females and males were 1.6 and 1.5 , respectively. The parameters of von Bertalanffy equation were calculated as $\mathrm{L}_{\infty}: 19.8 \mathrm{~cm}, \mathrm{~W}_{\infty}: 652.9 \mathrm{gr}$, k: 0.934 . In conclusion, C. gibelio has almost lost the economic value since the individuals are smaller than market size $(\geq 250 \mathrm{~g})$, probably due to lack of nutrients/mesotrophic situation of Lake Beyşehir.
\end{abstract}

Keywords: Beyşehir Lake, eutrophication, gonadosomatic index (GSI), length - weight relationship, von Bertalanffy equation

\section{Introduction}

The Beyşehir Lake, which is the biggest freshwater lake in Turkey, has some serious problems about sustainability of indigenous fish populations in recent years (Tekinay et al., 2013). Total production in the lake by commercial fishing has been decreasing since 2005 due to several reasons such as changes in bio-ecological conditions of the lake and uncontrolled fishing (Anonymous, 2013).

Eleven species (Cyprinus carpio, Chondrostoma regium, Leuciscus lepidus, Pseudophoxinus anatolicus anatolicus, Knipowitschia caucasica, Aphanius anatoliae anatoliae, Gambusia affinis, Sander lucioperca, Tinca tinca, Atherina boyeri, Carassius gibelio) belonging to 6 families were reported in the Beyşehir Lake (Çubuk et al., 2006; Yeğen et al., 2006). The last four of these species were introduced to the lake and apparently caused some impacts on the lake ecosystem, although this has not been proven yet. Gibel carp, which was introduced into Lake Beyşehir at the end of 1990s, was adapted to the local conditions (Çınar et al., 2007) and become the dominant species (Tekinay et al., 2013).

C. gibelio displays fast growth until sexual maturation and high survival rates. It is an omnivorous fish (Kottelat and Freyhöf, 2007), reproduces gynogenetically and has extensive tolerance to different environmental conditions (Ekmekçi, 2013). The reason for the intense reproductive success of introduced $C$. gibelio is its capacity for gynogenetic reproduction, whereby females are able to use sperm of other cyprinid fishes and salmonids to fertilize their eggs (Penaz et al., 1979; Tarkan et al., 2012). Consequently, this species easily becomes a dominant species in stagnant and slow running waters (Tsoumani et al., 2006).

Since body weight does not reach to market size $(\geq 250 \mathrm{~g})$ in Beyşehir Lake, plenty of uneconomical fish cause labor and time loss. This condition situation of species has been probably affected from the trophic status of lake. Also, biological characteristics of the species need to be determined in the lake to obtain useful information in order to prevent the invasion of C. gibelio, as well as for determining population sustainability of natural species and consequently sustainable fisheries in the lake. Therefore, the present study was designed to determine trophic status of lake and investigate population structure and some growth properties of $C$. gibelio.

\section{Materials and Methods}

\section{Fish and water sampling}

A monthly-sampling-study was carried out in 5 different areas (Tolca, Yeşildağ, Beyşehir Centre, Gölyaka and Çiftlik) in 
Lake Beyşehir (Konya, Turkey) (Fig. 1) between April 2013 and March 2014.

Water samples from each location were taken to determine chlorophyll-a and Trophic State Index (TSI) values. Chlorophyll-a measurements were carried out according to Stirling et al. (1985). Based on chlorophyll-a variance, TSI was detected. According to this procedure lakes are classified as low productive (TSI < 30), medium productive (TSI: 40-50) and high productive (TSI: 50-70) (Carlson, 1977; Carlson and Simpson, 1996).

Monofilament gill nets with the mesh sizes of $30,40,50,60$, $70,80,100,110$ and $120 \mathrm{~mm}$ and monofilament trammel nets with $130 \mathrm{~mm}$ mesh size, which received occupancy permission from the Republic of Turkey, Ministry of Food, Agriculture and Livestock, were layed within Lake Beysehir Ecosystem Rehabilitation Project. Also, multi-filament gill nets with the mesh sizes of 30, 40 and $50 \mathrm{~mm}$ and multi-filament trammel nets with 70 and $110 \mathrm{~mm}$ mesh sizes were used for C. gibelio sampling. Monthly sampled were taken, thus 59 to 346 (mean 156) individuals of species from five stations were investigated.

Fish samples were immediately transferred to Izmir Katip Çelebi University, Faculty of Fisheries Laboratories in cooler boxes.

\section{Qualitative analysis and statistical procedures}

For each sample, the total length (TL) was measured to the nearest $0.1 \mathrm{~cm}$ and the total weight (W) to the nearest $0.1 \mathrm{~g} .20$ scales were collected from each sample for age determination according to Lagler (1966) and Nikolsky (1963). After dissection, sex was determined by macroscopic observation, and gonad weights were weighed. Sex ratios, length and weight distribution and length - weight relationship were determined. Condition factor (as formulated CF $=\left(\mathrm{W} / \mathrm{L}^{3}\right) \times 100$ by Ricker (1975)) and gonadosomatic index (GSI) (as formulated GSI = $\left(\mathrm{W}_{\mathrm{G}} / \mathrm{W}_{\mathrm{T}}\right) \times 100$ by Wootton $\left.(1990)\right)$ were calculated. Water temperatures were also determined on monthly basis with Hach HQ40d Water Quality Multiparameter, in order to associate with GSI values. Also von Bertalanffy equation data were estimated according to $\mathrm{L}_{(\mathrm{t})}=\mathrm{L}_{\infty}{ }^{*}\left(1-\mathrm{e}^{-\mathrm{k}}\left(\mathrm{t}-\mathrm{t}_{0}\right)\right.$ in length and $\mathrm{W}_{\infty}=\mathrm{a}^{*} \mathrm{~L}_{\infty}$ in weight.

Statistical analyses were used to assess if the parameters (total length, weight, condition factor, gonadosomatic index) differed

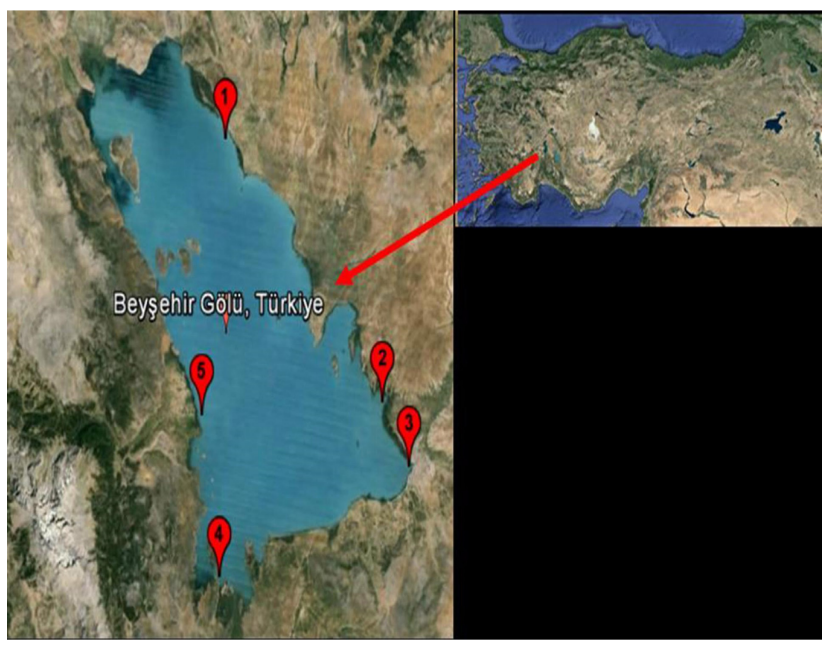

Fig. 1. Study area (Lake Beysehir) and sampling stations: 1. Tolca, 2. Ciftlik, 3. Beysehir Centre, 4. Yesildag, 5.Golyaka between seasons and sexes. The homogeneity of variances was tested (the Kolmogorov-Smirnov and Levene's test) and, whenever necessary, the log-transformation $\log (\mathrm{x}+1)$ was used.

One way analysis of variance (ANOVA) was used at the $5 \%$ significance level to determine differences among the mean results $(\mathrm{p} \leq 0.05)$. The Tukey-HSD test was applied when it was significant. A regression analysis was used to examine morphometric relations (length and weight) (Zar, 1999). All statistical analyses were carried out using Microsoft Excel and the IBM SPSS 21 Software package.

\section{Results}

The results of chlorophyll-a and TSI parameters were shown in Table 1. In autumn, both of these parameters have the highest values than during other seasons. The chlorophyll-a and TSI were determined as $26.19 \pm 3.59$ and $62.26 \pm 1.28$, respectively. The mean values were calculated as $9.26 \pm 2.19$ (chlorophyll- $a$ ) and $47.20 \pm 2.25$ (TSI) (Table 1).

Total length of 1,868 C. gibelio samples caught from Lake Beyşehir was determined in the range of 8.5 and 28.4 $\mathrm{cm}$. Minimum and maximum total lengths for female, male and unidentified individuals were detected as 11.0, 8.5 and $10.2 \mathrm{~cm}$ and 28.4, 25.9 and 27.1, respectively. The weight parameters varied between 15.0 and $408.0 \mathrm{~g}$; which minimum and maximum values for females as 21.0 and $408.0 \mathrm{~g}$, whereas for males these were 15.0 and $278.0 \mathrm{~g}$ and for unidentified individuals, they were 14.0 and $238.0 \mathrm{~g}$, respectively. Mean total length and weight of individuals were measured as $17.5 \pm 2.37 \mathrm{~cm}$ and $88.6 \pm 39.02 \mathrm{~g}$, respectively. Mean total length and weight of females were calculated as $18.4 \pm 2.46 \mathrm{~cm}$ and $105.8 \pm 44.29 \mathrm{~g}$, respectively. Also mean total length and weight of male individuals were determined as $17.1 \pm 2.04 \mathrm{~cm}$ and $79.0 \pm$ $29.51 \mathrm{~g}$, respectively (Table 2 ). In addition, $\mathrm{a}, \mathrm{b}$ and $\mathrm{R}^{2}$ rates were estimated as length-weight relationship values $0.017,2.959$ and 0.924 , respectively. A negative allometry (b: 2.959) was obtained length - weight relation (Fig. 2).

Research on the range of the age indicated that the fish in the Lake Beyşehir showed an alteration between II and VII years of age (Table 3). The age distribution of

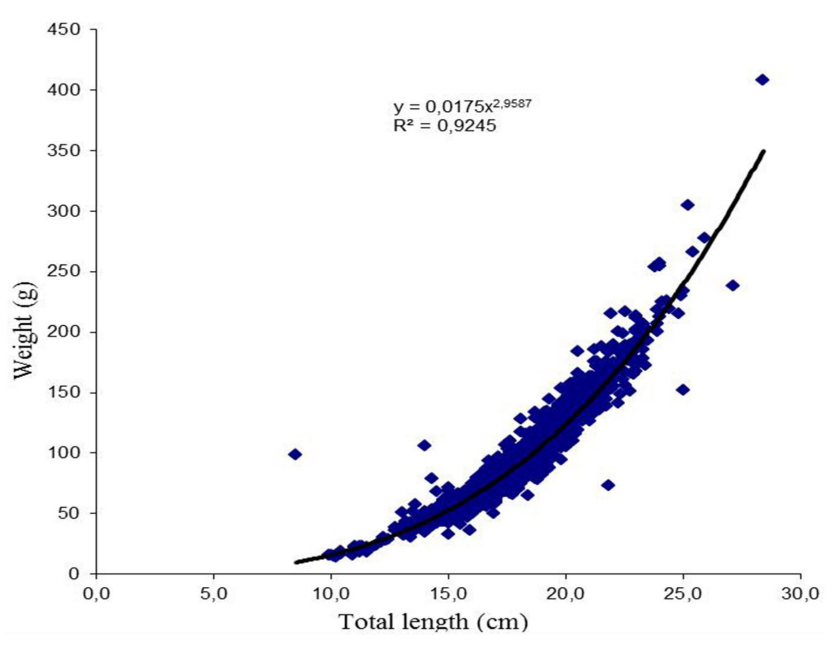

Fig. 2. Length-weight relationship of C. gibelio 
288

Table 1. Seasonal and mean chlorophyll- $a(\mathrm{Chl}-a)$ and Trophic State Index (TSI) values of Beyşehir Lake

\begin{tabular}{lccccc}
\hline & Winter & Spring & Summer & Autumn & Mean \\
\hline Chl-a $(\mu \mathrm{g} / \mathrm{lt})$ & $6.01 \pm 0.61$ & $3.36 \pm 0.88$ & $5.30 \pm 1.06$ & $26.19 \pm 3.59$ & $9.26 \pm 2.19$ \\
TSI & $48.07 \pm 1.05$ & $3.36 \pm 0.88$ & $46.33 \pm 1.95$ & $62.26 \pm 1.28$ & $47.20 \pm 2.25$ \\
\hline
\end{tabular}

Table 2. Total length and weight parameters of $C$. gibelio by sexes

\begin{tabular}{|c|c|c|c|c|c|c|c|c|}
\hline \multicolumn{5}{|c|}{ Total length $(\mathrm{cm})$} & \multicolumn{4}{|c|}{ Weight (g) } \\
\hline & Female & Male & Unidentified & Total & Female & Male & Unidentified & Total \\
\hline $\mathrm{n}$ & 708 & 780 & 380 & 1868 & 708 & 780 & 380 & 1868 \\
\hline Min - Max & $11.0-28.4$ & $8.5-25.9$ & $10.2-27.1$ & $28.4-8.5$ & $21.0-408.0$ & $15.0-278.0$ & $14.0-238.0$ & $408.0-14.0$ \\
\hline Mean $\pm S D$ & $18.4 \pm 2.5$ & $17.1 \pm 2.0$ & $16.7 \pm 2.3$ & $17.5 \pm 2.4$ & $105.7 \pm 44.3$ & $79.0 \pm 29.5$ & $76.6 \pm 34.3$ & $88.6 \pm 39.2$ \\
\hline
\end{tabular}

captured fishes between II and VII years were determined as $13.3,32.4,24.8,18.1,8.6$ and $2.9 \%$, respectively. Von Bertalanffy growth equation, which is based on the length and age parameters, is shown in Table $4 . \mathrm{L}_{\infty}, \mathrm{W}_{\infty}$ and $\mathrm{k}$ were calculated as $19.8 \mathrm{~cm}, 652.9 \mathrm{~g}$ and 0.934 , respectively (Table 4).

The condition factor (CF) values were validated between $1.5-1.7$ besides the mean rate of females and males were 1.6 and 1.5 , respectively (Fig. 3). Between the II and VII ages, condition factor values were determined 1.5, 1.6, 1.5, 1.6, 1.7 and 1.6, respectively. Gonado-somatic index (GSI) values of female individuals were showed in Fig. 3. Between April and June period it was prominent on account of spawning period. The water temperatures of Lake Beysehir were detected as $13.9^{\circ} \mathrm{C}$ for April, $19.5^{\circ} \mathrm{C}$ for May and $22.0^{\circ} \mathrm{C}$ for June, when the spawning period occurred. In this study, the male and female rate of the $C$. gibelio was determined as 1:1.1.

Statistical analyses of total length, weight, condition factor and gonadosomatic index values by sexes and seasons are shown in Table 5 and 6. It was determined that the values of mean total length and weight for female individuals were higher in all seasons than for the male individuals. Said length and weight difference between female and male individuals was found statistically significant (except for winter season, for total length) (Table 5 and 6). There were significant differences detected in GSI and CF values between sexes (Table 5). Not only between sexes, but also the values between seasons were determined as different in GSI and CF parameters statistically $(\mathrm{p} \leq 0.05)$ (Table 6$)$.

\section{Discussion}

Total length of 1,868 C. gibelio samples caught from Lake Beyşehir was in a range of 9.9-28.4 cm and it was detected that the individuals in Lake Beyşehir were smaller than the ones reported in other studies. For example, it was reported a total length distribution of 12.5-35.7 cm in Ömerli Dam Lake (Turkey) (Tarkan et al., 2006); $5.2-30.2 \mathrm{~cm}$ in Lake İznik (Turkey) (Tarkan et al., 2006); 8.5-33.3 cm in Lake Uluabat (Turkey) (Emiroğlu, 2008); 10.3-30.5 cm in Aksu River (Turkey) (Innal, 2012); 21.9-37.0 cm in Chimaditis Lake (Greece) (Leonardos et al., 2008).

The same finding also applies to the value of maximum theoretical length $\left(\mathrm{L}_{\infty}\right)(19.8 \mathrm{~cm})$ calculated for the species. For example, the value of $\mathrm{L}_{\infty}$ was reported as $36.2 \mathrm{~cm}$ for the same lake (Çınar et al., 2007); $31.7 \mathrm{~cm}$ for Buldan Lake (Sarı et al., 2008); $33.3 \mathrm{~cm}$ for Lake Eğirdir (Balık et al., 2004); 48.1 $\mathrm{cm}$ for Seyitler Dam Lake (Bulut et al., 2013) and $36.0 \mathrm{~cm}$ (female) and 32.2 (male) for Gelingüllü Dam Lake (Kırankaya and Ekmekçi, 2013). Differences in total lengths could be attributed to sampling time, sampling method and ecological properties of the working areas.

Mean total length for female and male individuals was detected as $18.4 \pm 2.46$ and $17.1 \pm 2.04 \mathrm{~cm}$ respectively, whereas mean weight was detected as $105.8 \pm 44.29$ and 79.0 $\pm 29.51 \mathrm{~g}$. It was determined that the values of mean total length and weight for female individuals were higher in all seasons than those of male individuals. Said length and weight difference between female and male individuals was found statistically significant (except for winter season for total length). Different researchers (Balık et al., 2004; Kırankaya

Table 3. Sex ratio, total length $(\mathrm{cm})$ and weight $(\mathrm{g})$ for different ages of $C$. gibelio

\begin{tabular}{|c|c|c|c|c|c|c|}
\hline & II & III & IV & V & VI & VII \\
\hline $\mathrm{N}$ & 14 & 34 & 26 & 19 & 9 & 3 \\
\hline$\%$ & 13.3 & 32.4 & 24.8 & 18.1 & 8.6 & 2.9 \\
\hline Mean TL \pm SD & $14.0 \pm 2.3$ & $16.8 \pm 2.2$ & $19.2 \pm 2.7$ & $19.0 \pm 2.6$ & $21.3 \pm 2.3$ & $21.9 \pm 2.2$ \\
\hline Mean $W \pm S D$ & $45.3 \pm 26+.2$ & $80.7 \pm 34.5$ & $113.9 \pm 49.8$ & $118.1 \pm 58.8$ & $167.7 \pm 60.5$ & $151.5 \pm 55.4$ \\
\hline Female n & 1 & 9 & 14 & 7 & 7 & 2 \\
\hline Female \% & 2.5 & 22.5 & 35.0 & 17.5 & 17.5 & 5.0 \\
\hline Male n & 8 & 14 & 4 & 9 & 1 & 1 \\
\hline Male \% & 21.6 & 37.8 & 10.8 & 24.3 & 2.7 & 2.7 \\
\hline
\end{tabular}

TL: Total length; W: Weight; SD: Standard deviation 
Table 4. C. gibelio length and age parameters

\begin{tabular}{ccccccccc}
\hline $\mathrm{n}$ & Minimum age & Maximum age & $\mathrm{a}$ & $\mathrm{b}$ & $\mathrm{R}^{2}$ & $\mathrm{~L}_{\infty}$ & $\mathrm{W}_{\infty}$ & $\mathrm{k}$ \\
\hline 146 & 2 & 7 & 11.991 & 0.393 & 0.815 & 19.755 & 652.907 & 0.934 \\
\hline
\end{tabular}

Table 5. Statistical analyses of C. gibelio individuals between sexes

\begin{tabular}{|c|c|c|c|c|c|c|c|c|}
\hline & \multicolumn{4}{|c|}{ Total length $(\mathrm{cm})$} & \multicolumn{4}{|c|}{ Weight (g) } \\
\hline & Spring & Summer & Autumn & Winter & Spring & Summer & Autumn & Winter \\
\hline Female & $20.3 \pm 0.22^{\mathrm{a}}$ & $17.6 \pm 0.21^{a}$ & $19.1 \pm 0.18^{\mathrm{a}}$ & $18.9 \pm 0.12$ & $140.7 \pm 4.41^{a}$ & $92.1 \pm 3.68^{\mathrm{a}}$ & $116.8 \pm 3.85^{a}$ & $108.5 \pm 2.11^{\mathrm{a}}$ \\
\hline \multirow[t]{3}{*}{ Male } & $19.1 \pm 0.35^{\mathrm{b}}$ & $16.5 \pm 0.19^{\mathrm{b}}$ & $17.3 \pm 0.16^{\mathrm{b}}$ & $18.5 \pm 0.09$ & $117.5 \pm 5.69^{\mathrm{b}}$ & $69.6 \pm 2.43^{b}$ & $80.5 \pm 3.55^{\mathrm{b}}$ & $96.8 \pm 1.52^{\mathrm{b}}$ \\
\hline & \multicolumn{4}{|c|}{$\mathrm{CF}$} & \multicolumn{4}{|c|}{ GSI } \\
\hline & Spring & Summer & Autumn & Winter & Spring & Summer & Autumn & Winter \\
\hline Female & $1.63 \pm 0.02^{\mathrm{a}}$ & $1.61 \pm 0.01^{a}$ & $1.60 \pm 0.01^{a}$ & $1.60 \pm 0.01^{a}$ & $8.73 \pm 0.60^{\mathrm{a}}$ & $1.48 \pm 0.12$ & $5.88 \pm 0.28$ & $6.14 \pm 0.23^{\mathrm{a}}$ \\
\hline Male & $1.79 \pm 0.22^{\mathrm{b}}$ & $1.53 \pm 0.02^{\mathrm{b}}$ & $1.53 \pm 3.65^{\mathrm{b}}$ & $1.51 \pm 0.01^{\mathrm{b}}$ & $2.26 \pm 0.19^{\mathrm{b}}$ & $2.47 \pm 1.37$ & $5.39 \pm 0.34$ & $3.14 \pm 0.13^{\mathrm{b}}$ \\
\hline
\end{tabular}

Table 6. Statistical analyses of $C$. gibelio individuals between seasons

\begin{tabular}{|c|c|c|c|c|}
\hline & \multicolumn{2}{|c|}{ Total length $(\mathrm{cm})$} & \multicolumn{2}{|c|}{$\begin{array}{l}\text { Weight }(\mathrm{g}) \\
\end{array}$} \\
\hline & Female & Male & Female & Male \\
\hline Spring & $20.3 \pm 0.22^{\mathrm{a}}$ & $19.1 \pm 0.35^{\mathrm{a}}$ & $140.7 \pm 4.41^{\mathrm{a}}$ & $117.5 \pm 5.69^{\mathrm{a}}$ \\
\hline Summer & $17.6 \pm 0.21^{\mathrm{b}}$ & $16.5 \pm 0.19^{\mathrm{b}}$ & $92.1 \pm 3.68^{\mathrm{b}}$ & $69.6 \pm 2.43^{b}$ \\
\hline Autumn & $19.1 \pm 0.18^{c}$ & $17.3 \pm 0.16^{\mathrm{c}}$ & $116.8 \pm 3.85^{\mathrm{c}}$ & $80.5 \pm 3.55^{\mathrm{a}}$ \\
\hline \multirow[t]{3}{*}{ Winter } & $18.9 \pm 0.12^{c}$ & $18.5 \pm 0.09^{\mathrm{d}}$ & $108.5 \pm 2.11^{\mathrm{c}}$ & $96.8 \pm 1.52^{c}$ \\
\hline & \multicolumn{2}{|c|}{$\mathrm{CF}$} & \multicolumn{2}{|c|}{ GSI } \\
\hline & Female & Male & Female & Male \\
\hline Spring & $1.63 \pm 0.02^{2 \mathrm{at}}$ & $1.79 \pm 0.22^{\mathrm{a}}$ & $8.73 \pm 0.60^{\mathrm{a}}$ & $2.26 \pm 0.19^{\mathrm{a}}$ \\
\hline Summer & $1.61 \pm 0.01^{\mathrm{a}}$ & $1.53 \pm 0.02^{2 \mathrm{~b}}$ & $1.48 \pm 0.12^{\mathrm{b}}$ & $2.47 \pm 1.37^{\mathrm{b}}$ \\
\hline Autumn & $1.60 \pm 0.01^{\mathrm{a}}$ & $1.53 \pm 3.65^{\mathrm{b}}$ & $5.88 \pm 0.28^{\mathrm{c}}$ & $5.39 \pm 0.34^{\mathrm{c}}$ \\
\hline Winter & $1.60 \pm 0.01^{\mathrm{b}}$ & $1.51 \pm 0.01^{\mathrm{b}}$ & $6.14 \pm 0.23^{c}$ & $3.14 \pm 0.13^{\mathrm{d}}$ \\
\hline
\end{tabular}

CF: Condition factor; GSI: Gonadosomatic index; ${ }^{a, b, c, d}$ There were statistically significant differences between the seasons $(\mathrm{p} \leq 0.05)$

and Ekmekçi, 2013) reported that female individuals were longer and heavier compared to male individuals, and $\mathrm{b}$ values in the length-weight relationship were calculated higher for females than males.

It was determined that the species showed a negative allometric growth in Lake Beyşehir. In other studies, similar to the hereby investigation, a negative allometry (Bulut et al., 2013; Kızına, 1986; Leonardos et al., 2008; Sar1 et al., 2008) as well as a positive allometry (Balık et al., 2004; Bostancı et al., 2007; Çınar et al., 2007; İnnal, 2012; Özkök et al., 2007; Tarkan et al., 2006) were detected. Differences in b value can be caused by age and maturity (Bulut et al., 2013); geographical location and environmental conditions (Bagenal and Tesch, 1978), season and nutrition (Tesch, 1968) and trophic state of the lake (Tsoumani et al., 2006). It was reported the relationship that as $\mathrm{b}$ value was reduced when the concentration of phosphate phosphorus $\left(\mathrm{PO}_{4}-\mathrm{P}\right)$, which trophic level indicator increased, the species exhibited better growth in mesotrophic and oligotrophic lakes, whereas the growth was affected negatively in eutrophic and hypertrophic lakes. On the other hand, Tarkan et al. (2012) reported that total phosphorus was not correlated with

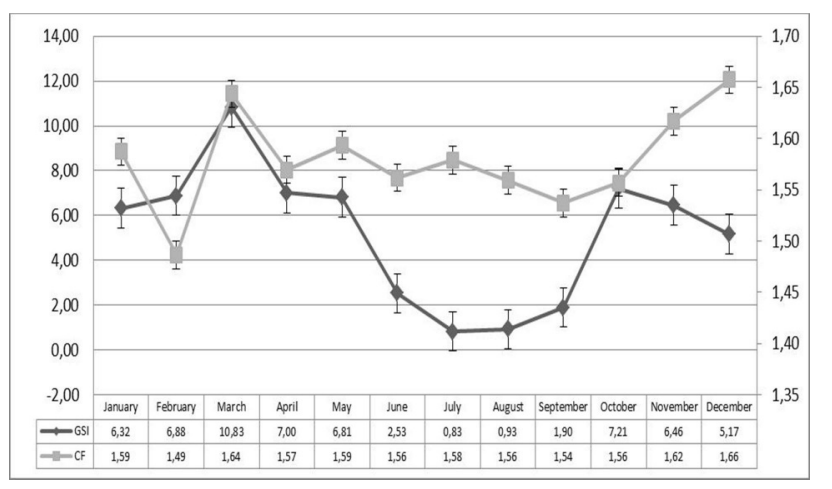

Fig. 3. Monthly changes in gonadosomatic index and condition factors of for female C. gibelio in the Beyşehir Lake

growth features of C. gibelio in a mesotrophic reservoir.

In the present study, Beyşehir Lake was classified as medium productive (mesotrophic lake) (TSI: 40-50) according to TSI values, since it has $47.20 \pm 2.25$ mean TSI value as stated in previous studies (Nas et al., 2008; Kazanc1 et al., 2009; Fakıoglu and Demir, 2011). It is thought that negative allometric growth of the species is correlated with the trophic state of Lake Beyşehir.

In Lake Beyşehir, the condition factor values for males and females of the species ranged between 1.5 to 1.7 and it was found to be lower than the values recorded within other studies (Balık et al., 2004; Bostancı et al., 2007; Çınar et al., 2007; Özkök et al., 2007; İnnal, 2012; Bulut et al., 2013; Kurankaya and Ekmekçi, 2013). The condition factor varies by the age of species, season, maturity, spawning period, nutritional status and environmental conditions (Çetinkaya et al., 2005). Balık et al. described that the condition factor values increased based on age. On the contrary, condition factor values did not increase based on age in Lake Beyşehir. This situation showed that the species does not exhibit the expected growth.

In the current study, the age range of the caught fish was determined as II-VII. In a previous study upon Lake Beyşehir, the age range was determined as $0-\mathrm{V}$ (Çınar et al., 2007). In the study, the age group, III and IV constituted approximately half of the population (57.2\%). The same 
290

situation was reported for many populations in Europe (Szczerbowski, 2001) and Turkey (Balık et al., 2004; Sarı et al., 2008; Kırankaya and Ekmekçi, 2013). It is believed that in Lake Beyşehir the age group III (mean total length: $16.8 \mathrm{~cm}$ ) and IV (mean total length: $19.2 \mathrm{~cm}$ ), in population of the species is dominant, since the outsized individuals are caught because of their commercial value and the small individuals are not targeted. The small individuals which are incidentally caught on the gill net are returned to the lake and this causes labour and time loss.

In Lake Beyşehir, the male and female rate of the species was determined as 1:1.1 and when considered the values in previous studies (1:0.92) (Çınar et al., 2007), it is believed that the population prefers bisexual reproduction. Conversely, it is reported that the reproduction strategy is gynogenesis in many population in which the female individuals are dominant (Vetemaa et al., 2005; Tarkan et al., 2006; Tsoumani et al., 2006; Bostanci et al., 2007; Leonardos et al., 2008; Sar1 et al., 2008; Şaşı, 2008; Liasko et al., 2010; Bulut et al., 2013). In gynogenesis reproduction, gynogenetic females use the sperms of a male of their kind or the males of another carp species to fertilize the eggs and to induce reproduction, but sperms does not have any genetic effect on reproduction (Penaz et al., 1979). By means of this reproduction type, the species become dominant in habitat in a short time. Thus, the reproduction type of the species should be determined exactly through the genetic studies in Lake Beyşehir.

In Lake Beyşehir, the spawning period was determined between April and June, following March, in which GSI reached the peak value. In a similar manner with the hereby results, the beginning of the spawning period in different fish populations in Turkey was between March-April (Balık et al., 2004; Şaşı, 2008; Tarkan et al., 2006; Kırankaya and Ekmekçi, 2013). The spawning period of the species depends on environmental factors such as photoperiod and water temperature (Wootton, 1990). Thus, some alteration may appear in population in different geographical regions. It was determined that the spawning period of the species in populations in Europe begins in May-June, when the temperature is higher $\left(18-19^{\circ} \mathrm{C}\right)($ Szczerbowski, 2001), while the spawning period begins in April at a temperature of 13.9 ${ }^{\circ} \mathrm{C}$ in Lake Beyşsehir.

\section{Conclusions}

In conclusion, Carassius gibelio has almost lost the economic value since the individuals are smaller than market size, probably due to lack of nutrients/mesotrophic situation of Lake Beyşehir. In addition, this species is able to reproduce gynogenetically, which involves the use of sperm from males of other species to activate egg development, so reproductive competition is a likely, but virtually unstudied, impact of gibel carp on native populations. It has been reported that a dramatic decrease in the relative stocks of native fish species was significantly correlated with an increase in C. gibelio population. Thus, further studies are required in order to reveal the impacts of $C$. gibelio on native fish stocks and sustainable fisheries in mesotrophic lake.

\section{Acknowledgements}

The authors thank to Erol Erdoğan president of the fishing cooperative and fishermen for their help in field work. The authors also thank Prof. Dr. Ahmet Adem Tekinay and Dr. Haşim Sömek for their valuable comments and suggestions. This study was supported by the Ministry of Forestry and Water Affairs (Lake Beysehir Ecosystem Rehabilitation Project) and Coordinatorship of Scientific Research Projects of İzmir Katip Çelebi University (Project no.: 2014-1-TEZ-42).

\section{References}

Anonymous (2013). Catch values of the Beysehir Lake (in Turkish). Ministry of Food, Agriculture and Livestock, Konya Provincial Directorate.

Bagenal TB, Tesch FW (1978). Age and growth. In: Methods for assessment of fish production in fresh waters. Bagenal TB (Ed) Blackwell Science Publication, Oxford, UK pp 101-136.

Balık İ, Özkök R, Çubuk H, Uysal R (2004). Investigation of some biological characteristics of the Gibel Carp, Carassius gibelio (Bloch, 1782) Population in Lake Eğirdir. Turkish Journal ofZoology 28:19-28.

Bostancı D, Polat N, Kandemir Ş, Y Ylmaz S (2007). Determination of condition factor and length-weight relationship of the Crucian Carp, Carassius gibelio (Bloch, 1782) inhabiting Bafra Fish Lake. SDU Fen Edebiyat Fakültesi Fen Dergisi 2(2):117-125.

Bulut S, Mert R, Algan B, Özbek M, Ünal B, Konuk M (2013). Several growth characteristics of an invasive Cyprinid Fish (Carassius gibelio Bloch, 1782). Notulae Scientia Biologicae 5(2):133-138.

Carlson RE (1977). A trophic state index for lakes. Limnology and Oceanography 22:361-369.

Carlson RE, Simpson J (1996). A coordinator's guide to volunteer lake monitoring methods. North American Lake Management Society pp 96.

Cetinkaya O, Sen F, Elp M (2005). Growth and growth analysis in fish research. In: Techniques in fish biology, 1st ed. Karatas M (eEd). Nobel Press, Ankara, Turkey pp 93-350.

Çınar Ş, Çubuk H, Özkök R, Tümgelir L, Çetinkaya S, Erol KG, Ceylan M (2007). Growth features of gibel carp (Carassius gibelio Bloch, 1782) population in Lake Beyşehir. Turkish Journal of Fisheries and Aquatic Sciences 5(8):401-409.

Çubuk H, Balık İ, Yağcı M, Çınar Ş (2006). The effects of new fish species which introduced afterwards in Lake Beysehir on lake ecosystem (in Turkish). I. International Beyşehir Symposium 1113 May 2006.

Ekmekçi FG (2013). Present status of invasive fishes in inland waters of Turkey and assessment of the effects of invasion (in Turkish). Istanbul University Journal of Fisheries \& Aquatic Sciences 28(1):105-140.

Emiroğlu Ö (2008). The investigation of bioecological features of Esox lucius Linnaeus, 1758, Carassius gibelio (Bloch, 1782) and Scardinius erythophthalmus (Linnaeus, 1758) populations in Lake 
Uluabat (Bursa) (in Turkish). Eskişehir Osmangazi University, Institute of Science, Department of Hydrobiology, $\mathrm{PhD}$ Thesis.

Fakıoğlu F, Demir N (2011). The spatial and seasonal variations of phytoplankton biomass in Lake Beysehir. Ekoloji 20(80):23-32.

Innal D (2012). Age and growth properties of Carassius gibelio (Cyprinidae) living in Aksu River Estuary (Antalya-Turkey). International Review of Hydrobiology 5(2):97-109.

Kazancı N, Oğuzkurt DG, Dügel M (2009). Multivariate analysis of phytoplankton assemblages in Beyşehir Lake (Turkey) as a tool of water quality monitoring and management. Review of Hydrobiology 1:45-56.

Kurankaya ŞG, Ekmekçi FG (2013). Life - History traits of the invasive population of Prussian Carp, Carassius gibelio (Actinopterigi: Cypriniformes: Cyprinidae), from Gelingüllü Reservoir, Yozgat, Turkey. Acta Ichthyologica et Piscatoria 43(1):31-40.

Kizına LP (1986). Some data on the biology of the genus Carassius from the lower reaches of the Volga Delta. Journal of Ichthyology 26(4):31-40.

Kottelat M, Freyhöf J (2007). Handbook of European fresh water fishes. Luxembourg: Publications office of the European Union publications office. Publications Kotellat. doi: 10.2779/85903 .

Lagler KF (1966). Fresh water fishery biology. W.M.C. Brown Company, Iowa pp 471.

Leonardos ID, Tsikliras AC, Eleftheriou V, Cladas Y, Kagalou I, Chortatou R, Papigioti O (2008). Life history characteristics of an invasive Cyprinid Fish (Carassius gibelio) in Chimaditis Lake (Northern Greece). Journal of Applied Ichthyology 24:213-217.

Liasko R, Liousia V, Vrazeli P, Papiggioti O, Chortatou R, Abatzopoulos TJ, Leonardos ID (2010). Biological traits of rare males in the population of Carassius gibelio (Actinopterygii: Cyprinidae) from Lake Pamvotis (North-West Greece). Journal of Fish Biology 77:570-584.

Nas B, Karabork H, Ekercin S, Berktay A (2008). Assessing water quality in the Beyşehir Lake (Turkey) by the application of GIS, geostatistics and remote sensing. Sengupta M, Dalwani R (Eds). In: Proceedings of Taal 2007: The 12th World Lake Conference pp 639-646.

Nikolsky GV (1963). The ecology of fishes. Academic Press, New York, London pp 352.

Özkök R, Çubuk H, Tümgelir L, Uysal R, Çınar Ş, Küçükkara R, ... Ceylan M (2007). Growth features of Gibel carp (Carassius gibelio Bloch, 1782) population in Lake Eğirdir (in Turkish). Turkish Journal of Fisheries and Aquatic Sciences 3(5):5-8.

Penaz M, Rab P, Prokes M (1979). Cytological analysis, gynogenesis ande development of Carassius auratus gibelio. Acta Scientiarum Naturalium Brno 13:1-33.

Ricker WE (1975). Computation and interpretation of biological statistics of fish populations. Journal of the Fisheries Research Board of Canada 191:382.
Sarı HM, Balık S, Ustaoğlu MR, Ilhan A (2008). Population structure, growth and mortality of Carassius gibelio (Bloch, 1782) in Buldan Dam Lake.Turkish Journal of Fisheries and Aquatic Sciences 8:25-29.

Stirling HP, Beveridge MCM, Ross LG, Philips MJ (1985). Chemical and biological methods of water analysis for aquaculturalists. Institute of Aquaculture.

Szczerbowski JA (2001). Carassius Jarocki, 1822. In: The fresh water fishes of Europe. Vol 5. Cyprinidae 2. Part 3. Carassius to Cyprinus. Gasterosteidae. Bănărescu PM, Paepke HJ (Eds). AulaVerlag, Wiebelsheim, Germany pp 1-78.

Şaşı $H$ (2008). The length and weight relations of some reproduction characteristics of Prussian carp, Carassius gibelio (Bloch, 1782) in the South Aegean region (Aydın-Turkey). Turkish Journal of Fisheries and Aquatic Sciences 8:87-92.

Tarkan AS, Gaygusuz Ö, Gürsoy Gaygusuz Ç, Saç G, Copp GH (2012). Circumstantial evidence of gibel carp, Carassius gibelio, reproductive competition exerted on native fish species in a mesotrophic reservoir. Fisheries Management and Ecology 19(2):167-177.

Tarkan AS, Gaygusuz Ö, Gürsoy Ç, Acıpınar H, Bilge G (2006). A new predator species Carassius gibelio (BLOCH, 1782) in Marmara region: Successful or not (in Turkish). Fisheries and Reservoir management Symposium 07-09 February 2006, Antalya pp 195-204.

Tesch FW (1968). Age and growth in methods for assessment of fishes production in fresh water. In: IBP Handbook. Ricker WE (Ed). Blackwell Sci. Pub, No. 3 pp 93-123.

Tekinay AA, Dereli H, Sömek H, Dinçtürk E (2013). Lake Beysehir National Park ecosystem rehabilitation project (in Turkish). Ministry of Forestry and Water Affairs Directorate of $8^{\text {th }}$ District Konya.

Tsoumani M, Liasko R, Moutsaki P, Kagalou I, Leonardos I (2006). Length-weight relationships of an invasive Cyprinid fish (Carassius gibelio) from 12 Greek Lakes in relation to their trophic states. Journal of Applied Ichthyology 22:281-284.

Vetemaa M, Eschbaum R, Albert A, Saat T (2005). Distribution, sex ratio and growth of Carassius gibelio (Bloch) in coastal and inland water of Estonia (North-Eastern Baltic Sea). Journal of Applied Ichthyology 21:287-291.

Wootton RJ (1990). Ecology of Teleost Fishes. Chapman and Hall, London.

Yeğen V, Balık S, Bostan H, Uysal R, Bilçen E (2006). Recent status of fish faunas in some lakes and dams in lakes region (in Turkish). I. Fisheries and Reservoir management Symposium 7-9 February pp 129-140.

ZarJH (1999). Biostatistical analysis. Prentice-Hall. New Jersey. 